Journal homepage: www.aesacademy.org

\title{
Effects of different application methods of chitosan on growth, yield and quality of tomato (Lycopersicon esculentum Mill.)
}

\author{
M.A. Parvin ${ }^{1}$, H.M. Zakir ${ }^{1^{*}}$ (D) , Naznin Sultana ${ }^{1}$, A. Kafi ${ }^{2}$ and H.P. Seal ${ }^{1}$ \\ ${ }^{1}$ Department of Agricultural Chemistry, Bangladesh Agricultural University, Mymensingh - 2202, BANGLADESH \\ ${ }^{2}$ Lecturer (Agriculture), Hena Islam College, Challisa, Netrokona Sadar, Netrokona, BANGLADESH \\ "Corresponding author's E-mail: zakirhm.ac.bau@gmail.com
}

\section{ARTICLE HISTORY}

Received: 11 June 2019

Revised received: 20 July 2019

Accepted: 23 August 2019

\section{Keywords}

Chitosan

Foliar application

Tomato (Lycopersicon esculentum)

Treatment combinations

Yield and quality

\begin{abstract}
A pot experiment was conducted to study the effect of different application methods of chitosan on growth, yield and quality of tomato (Lycopersicon esculentum Mill.). The experiment was laid out in completely randomized design (CRD) with four replications and twelve treatments combinations viz., $T_{0}=$ Control, $T_{1}=$ Soil application of chitosan (SAC) @80 ppm, $T_{2}=S A C$ @120 ppm, $T_{3}=$ Foliar spraying of chitosan (FSC) @60 ppm, $T_{4}=$ FSC @80 ppm, $T_{5}=$ FSC @100 ppm, $T_{6}=$ Combination of $T_{1}$ and $T_{3}, T_{7}=$ Combination of $T_{1}$ and $T_{4}, T_{8}=$ Combination of $T_{1}$ and $T_{5}, T_{9}=$ Combination of $T_{2}$ and $T_{3}, T_{10}=$ Combination of $T_{2}$ and $T_{4}$, and $T_{11}=$ Combination of $T_{2}$ and $T_{5}$. The study results revealed that there were significant variations among the treatments on number of leaves, number of flower clusters, flowering duration, fruit length and yield of tomato. The highest yield of tomato was obtained from the treatment $T_{6}$, while the lowest was obtained from control treatment. Vitamin-C and lycopene content of tomato fruits varied from 2.19-4.09 and 2.38-3.58 mg $100 \mathrm{~g}^{-1}$ sample, respectively. Among the major minerals, the highest amounts of $\mathrm{Ca}, \mathrm{Mg}, \mathrm{Na}, \mathrm{K}, \mathrm{S}$ and $\mathrm{P}$ were obtained from $\mathrm{T}_{7}(0.69 \%), \mathrm{T}_{3}(0.58 \%), \mathrm{T}_{8}$ (0.38\%), $\mathrm{T}_{1}(0.62 \%), \mathrm{T}_{4}(0.15 \%)$ and $\mathrm{T}_{6}(0.33 \%)$ treatments, respectively. Study results inferred that the treatment $\mathrm{T}_{4}$ was more effective concerning most of the growth and biochemical parameters of tomato Finally, the study concluded that foliar application of chitosan alone or in combination with soil has significant effect on growth, yield and biochemical characters of tomato.
\end{abstract}

(C)2019 Agriculture and Environmental Science Academy

Citation of this article: Parvin, M.A., Zakir, H.M., Sultana, N., Kafi, A. and Seal H.P. (2019). Effects of different application methods of chitosan on growth, yield and quality of tomato (Lycopersicon esculentum Mill.). Archives of Agriculture and Environmental Science, 4(3): 261-267, https://dx.doi.org/10.26832/24566632.2019.040301

\section{INTRODUCTION}

Chitosan is a natural biopolymer which stimulates growth and increases yield of plants as well as induces the immune system of plants (Pongprayoon et al., 2013; Sultana et al., 2019). It can be extracted from the marine crustacean like prawn, shrimps, crab or from the exoskeletons of most insects. They are inherent to have specific properties of being environmentally friendly and easily degradable (Boonlertnirun et al., 2008). Moreover, chitosan not only activates the cells, but also improves its disease and insect resistant ability at field and storage (Doares et al., 1995; Bittelli, et al., 2001; Sultana et al., 2019). Application of chitosan in agriculture, even without chemical fertilizer, can increase the microbial population by large numbers, and transforms organic nutrient into inorganic nutrient, which is easily absorbed by the plant roots (Bolto et al., 2004). Moreover, plants treated with chitosan may be less prone to environmental stress such as drought, salinity and temperature (LizarragaPauli et al., 2011; Jabeen and Ahmad 2013; Pongprayoon et al., 2013).

Nowadays, consumers demand for more natural, safe food, with high quality and a prolonged shelf life, and without any chemical preservatives (Gol et al., 2013). Worldwide chitosan is treated not only as a promising and economic source for efficient and versatile crop protection material, but also as an environmental friendly, biocompatible and biodegradable polymer with various 
applications (Geisberger et al., 2013; Zhang et al., 2012). Thus chitosan has a wide scope of use in different field of agriculture viz. crop production and protection, storage, nutritional quality etc. In the meantime, chitosan has been extensively used as a bioactive fungicide (Dutta et al., 2009; Miao et al., 2014; Gabriela et al., 2016), bactericides (No et al., 2002) and as edible coatings at preharvest and postharvest stage to preserve the quality of many fruits and vegetables (Meng et al., 2008; Huang et al., 2012; Sultana et al., 2019). But there are scanty of research on effect of chitosan on growth and nutritional qualities of crops and vegetables.

Tomato (Lycopersicon esculentum Mill.) is widely grown not only in Bangladesh but also in many countries of the world for its taste and nutritional status. The estimated annual production of tomato in Bangladesh was 385 thousand metric tons in 20172018 fiscal year (BBS, 2019), which is not enough to meet up local demand for the country. The most logical way to increase the total production at the national level from our limited land resources is to increase yield per unit area. Application of plant growth promoter (PGP) seems to be one of the important practices in view of convenience, cost and labor efficiency. Recently, there has been global realization of the important role of PGP in agriculture for better growth and yield of crops and vegetables. Developed countries like Japan, China, Poland, South Korea etc. have long been using PGPs to increase crop yield. But use of synthetic PGPs are not good for the consumers, and recently peoples would like to avoid those products. On the contrary, chitosan is fully natural and safe for human consumption, which stimulates vital processes of plants through physiological and biochemical processes, and to changes on the molecular level related to expression of genes (Hadwiger, 2013; Nguyen Van et al., 2013). Considering the fact stated above, the present research work was undertaken to study the effect of different application methods of chitosan on growth, yield and quality attributes of tomato (Lycopersicon esculentum Mill.) as well as to recommend an application method of chitosan for tomato production in Bangladesh.

\section{MATERIALS AND METHODS}

\section{Experimental design}

The experiment was laid out in a completely randomized design (CRD) with 4 replications. Thus, the total numbers of pots were $48(12 \times 4)$ used for the experiment. The treatments were randomly distributed to the net house of the Department of Agricultural Chemistry of BAU, during the period of November 2016 to March 2017. The place of a pot was changed with others time to time to reduce environmental heterogeneity. The pots were prepared 15 days prior to transplant of the tomato seedlings. The collected soil was air dried first and then sun dried. Then soils were ground and subsequently sieved by using a $2 \mathrm{~mm}$ stainless steel sieve. All kinds of weeds, stubbles and residues of crop and weeds were removed from the soil. After then $8.0 \mathrm{~kg}$ powered soil was poured in each plastic bucket and kept undisturbed up to transplant of the tomato seedlings.
Treatments for the experiment

There were 12 treatments for the experiment. Both soil and foliar application of chitosan was incorporated in the experiment. The treatment combinations for the experiment was as follows- $T_{0}=$ Control, $T_{1}=$ Soil application of chitosan (SAC) @80 ppm, $\mathrm{T}_{2}=\mathrm{SAC} @ 120$ ppm, $\mathrm{T}_{3}=$ Foliar spraying of chitosan (FSC) @60 ppm, $T_{4}=$ FSC @80 ppm, $T_{5}=$ FSC @100 ppm, $T_{6}=$ Combination of $T_{1}$ and $T_{3}, T_{7}=$ Combination of $T_{1}$ and $T_{4}, T_{8}=$ Combination of $T_{1}$ and $T_{5}, T_{9}=$ Combination of $T_{2}$ and $T_{3}, T_{10}=$ Combination of $T_{2}$ and $T_{4}$, and $T_{11}=$ Combination of $T_{2}$ and $T_{5}$.

\section{Cultivation practices}

The experiment was conducted with the seedlings of tomato (Lycopersicon esculentum) var. Ruma-VF. The seedlings were collected from the Horticulture Center, Kewatkhali, Mymensingh, Bangladesh and transplanted on November 12, 2016. Intercultural operations viz. weeding, irrigation, disease and pest management were done using traditional methods as and when necessary. Fertilizers applied in the pot as recommended for high yield goal and medium soil fertility status as described in Fertilizer Recommendation Guide (FRG, 2012). The recommended dose of nitrogen, phosphorus and potassium were 60, 19 and $38 \mathrm{~kg} \mathrm{ha}^{-1}$ and fertilizer source were urea, TSP and MoP, respectively. Among the fertilizers, only TSP was applied to the individual pots during final preparation according to the recommendation. Urea and MoP were applied in two equal installments: first split was applied at 15 days after transplanting of seedlings and second split of urea and Mop were applied at 35 days after transplanting of seedlings. No manure was used in the experiment.

Purified chitosan @ 80 and 120 ppm were applied to the soils as mentioned in the treatments during final pot preparation. As the measured amount of chitosan was very small, first the volume was increased by mixing with few grams of soils of the respective pot and then this soil (chitosan+soil) was thoroughly mixed with the whole soil of the respective pot to maintain homogeneity. There were 4 types of spray solutions of chitosan viz. control (0 ppm), 60 ppm, 80 ppm and 100 ppm used for foliar application to tomato plants. The $\mathrm{pH}$ of the solution was adjusted to 5.0 with $0.1 \mathrm{M} \mathrm{NaOH}$ solution. $25 \mathrm{~mL}$ glacial acetic acid solution (diluted to $1.0 \mathrm{~L}$ with distilled water and $\mathrm{pH}$ adjusted to 5.0 with $0.1 \mathrm{M}$ $\mathrm{NaOH}$ solution) without chitosan was used as control. Solutions of chitosan were applied 6 times at an interval of 15 days, which starts from 25 days after transplanting (DAT). The spray was done by a hand sprayer at afternoon and required total volume of solution was $400 \mathrm{~mL}$ for each pot.

\section{Chemical analyses of tomato (L. esculentum) fruits}

One fully matured light yellow tomato fruit sample from each pot was collected for the determination of total titratable acidity and vitamin-C. Total titratable acidity was estimated by the visual titration method by neutralizing the acid with $0.1 \mathrm{M} \mathrm{NaOH}$ using 2 drops of phenolphthalein as an indicator. On the other hand, vitamin-C content in tomato fruit was estimated based on the reduction of 2,6-dichlorophenol indophenol dye as outlined 
by Sadasivam and Manickam (1996). Lycopene is responsible for the red colour of tomato. For the determination of lycopene content, a fully ripened tomato fruit sample was collected from each pot. The carotenoids in the sample are extracted in acetone and then taken up in petroleum ether following the method described by Sadasivam and Manickam (1996).

To determine different mineral elements ( $\mathrm{Ca}, \mathrm{Mg}, \mathrm{P}, \mathrm{K}, \mathrm{Na}$ and $\mathrm{S}$ ), another tomato fruit sample collected from each pot was cut into small pieces using a sharp stainless steel knife and dried in an electric oven at $50^{\circ} \mathrm{C}$ temperature for about $72 \mathrm{hrs}$. Then the samples were ground by a grinding mill and used to prepare tomato fruit extract by wet oxidation method using di-acid mixture as described by Singh et al. (1999). Among the nutrient elements, $\mathrm{Ca}$ and $\mathrm{Mg}$ were determined by titrimetrically, $\mathrm{P}$ and $\mathrm{S}$ were measured by spectrophotometrically, and $\mathrm{Na}$ and $\mathrm{K}$ were estimated by flame photometrically as mentioned by Singh et al. (1999).

\section{Data collection and statistical analysis}

Data on plant height and number of leaves were recorded at 30 , $40,50,60,70$ and 80 days after transplanting (DAT). Number of flower clusters was counted from each plant at 80 DAT. Fruit length, fruit diameter, number of fruits plant ${ }^{-1}$, single fruit weight and yield plant ${ }^{-1}$, were recorded at harvest, and then the average data were used in this study. Obtained data were analysed statistically and the mean differences of the treatments were adjusted by least significant difference (LSD) test with the help of computer package M-STAT.

\section{RESULTS AND DISCUSSION}

Effect of chitosan application on morphological characters of tomato (L. esculentum)

Effect of different application methods and concentrations of chitosan on plant height of tomato (L. esculentum) at different DAT are presented in Figure 1 and there were no significant variations among the treatments at different DAT. But it is evident from Figure 1 that the highest plant height was recorded by the application of $\mathrm{T}_{4}$ treatment (foliar application of chitosan @ 80 ppm) at all DAT. Results revealed that plant height was greater

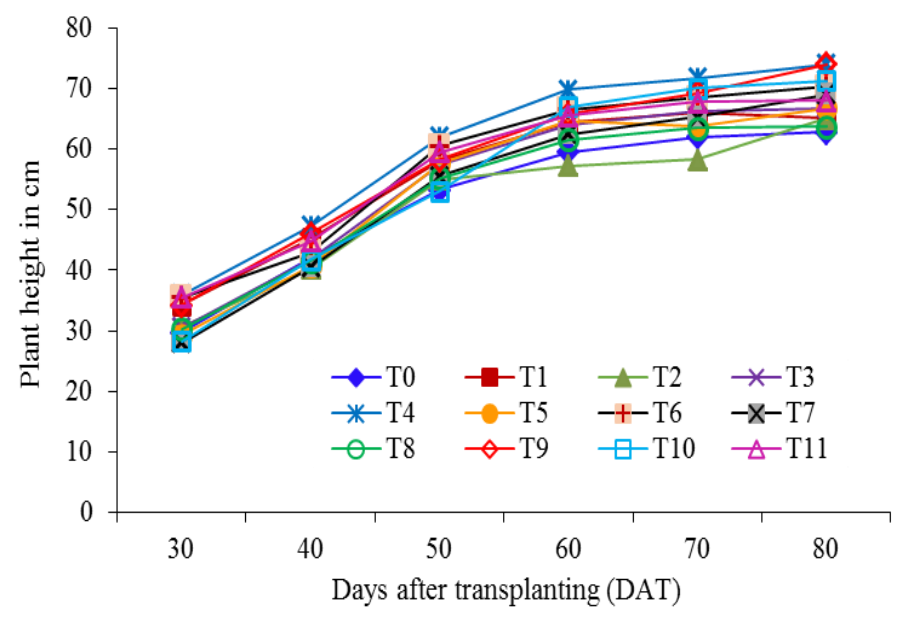

Figure 1. Effect of different application methods and doses of chitosan on plant height of tomato (L. esculentum) at different days after transplanting (DAT). in chitosan applied tomato (L. esculentum) plants than control plants. The longest plant was obtained in $\mathrm{T}_{4}$ treatment $(74.00$ $\mathrm{cm}$ ) followed by $\mathrm{T}_{9}$ and $\mathrm{T}_{10}$ at $80 \mathrm{DAT}$. Control plant produced the shortest plant height $(62.75 \mathrm{~cm})$ at 80 DAT. Similar result was also reported by El-Tantawy (2009) who reported that plant height in tomato (L. esculentum) increased with the application of chitosan. Sultana et al. (2017) reported that foliar spraying of oligo-chitosan with different concentrations (60 and 100 ppm) has positive effect on plant height of tomato at different days after sowing. Mondal et al. (2016) also reported that foliar application of chitosan (25, 50, 75 and 100 ppm) at early growth stages increased plant height of summer tomato (L. esculentum). Chitosan has been reported as a high potential biomolecule had molecular signals that served as plant growth promoters (Gornik et al. 2008). Recently some researchers reported that the stimulating effect of chitosan on plant growth may be attributed to an increase in key enzymes activities of nitrogen metabolism (nitrate reductase, glutamine synthetase and protease) and improved the transportation of nitrogen in the functional leaves which enhanced plant growth and development (Khan et al., 2002; Gornik et al., 2008).

Effect of different application methods and concentrations of chitosan on number of leaves plant ${ }^{-1}$ of tomato (L. esculentum) at different DAT are presented in Figure 2. There were significant variations among the treatments at 40,50 and 80 DAT. It is evident from Figure 2 that the highest number of leaves plant ${ }^{-1}$ of tomato was recorded by the application of $T_{4}$ treatment (foliar application of chitosan @ 80 ppm) at 50, 70 and 80 DAT. Results revealed that foliar application of chitosan had significant positive effect to increase number of leaves plant ${ }^{-1}$ of tomato (L. esculentum) than soil application of chitosan. The maximum number of leaves plant ${ }^{-1}$ of tomato was obtained in $\mathrm{T}_{4}$ treatment (36.75) followed by $T_{5}, T_{7}$ and $T_{10}$ treatments at 80 DAT. Treatment $T_{1}$ produced the minimum number of leaves plant $^{-1}$ of tomato (24.00), which was statistically similar with $T_{2}$ and control treatments at 80 DAT. The result obtained from the present study is consistent with the result of El-Tantawy (2009) who stated that leaf number in tomato plants increased with the application of chitosan than control plants.

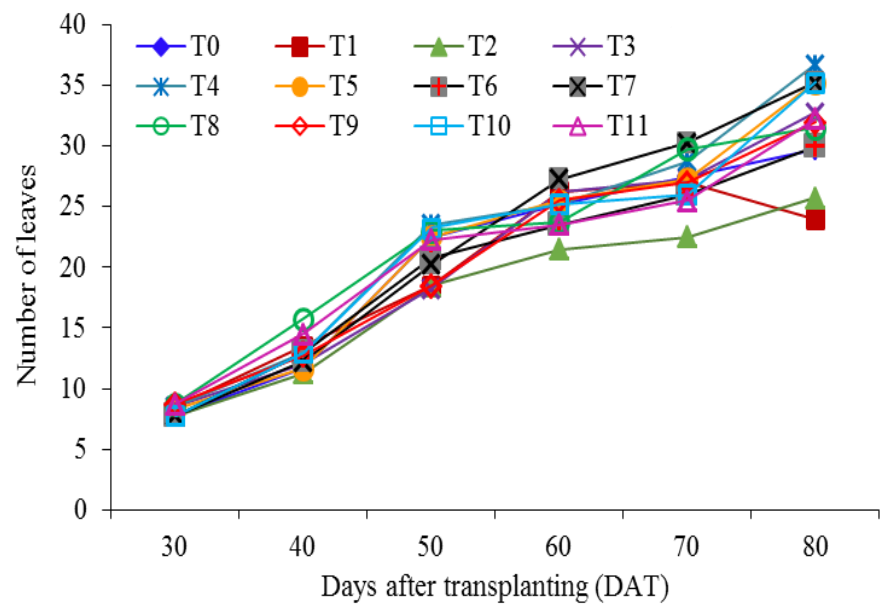

Figure 2. Effect of different application methods and doses of chitosan on number of leaves of tomato at different days after transplanting (DAT). 
Effect of chitosan application on reproductive characters of tomato (L. esculentum)

Different application methods and concentrations of chitosan showed significant effect on number of flower clusters plant ${ }^{-1}$ and flowering duration of tomato (Table 1). The average number of flower clusters plant ${ }^{-1}$ of tomato varied from 9.75-13.75 with a mean value of 12.02 among the treatments. The maximum number of flower clusters plant ${ }^{-1}$ of tomato was recorded in treatments both $T_{5}$ and $T_{7}$, while the minimum numbers of flower cluster plant ${ }^{-1}$ was obtained from control treatment (Table 1). Results revealed that different application methods of chitosan had significant positive effect to increase number of flower clusters plant ${ }^{-1}$ of tomato. Similar result was also reported by Sultana et al. (2017), and they stated that foliar spraying of oligo -chitosan with different concentrations (60 and 100 ppm) has positive effect on number of flower clusters plant ${ }^{-1}$ of tomato at different days after sowing. Mondal et al. (2016) also found that the number of effective flower cluster and flowers plant ${ }^{-1}$ were greater in chitosan $(25,50$ and $75 \mathrm{ppm})$ applied to summer tomato (L. esculentum) plants than control plants. On the other hand, the average flowering duration of tomato varied from 65.00-81.50 days with a mean value of 72.21 days. The maximum flowering duration of tomato was recorded in treatment $T_{6}$, which was statistically at par with the treatments $T_{3}$ and $T_{9}$, while the minimum duration was obtained from control treatment (Table 1). Results revealed that different application methods of chitosan had significant positive effect to flowering duration of tomato (L. esculentum). Mondal et al. (2016) also stated that foliar application of chitosan increased reproductive efficiency of summer tomatoes and thereby increased the prime yield component.

Effect of different application methods and levels of chitosan had no significant effect on fruit length and diameter of tomato (L. esculentum). The average fruit length of tomato varied from $4.05-4.65 \mathrm{~cm}$ with a mean value of $4.40 \mathrm{~cm}$ (Table 1). The highest fruit length of tomato was obtained from the treatment $T_{2}$ (i.e. soil application of chitosan @ 120 ppm) followed by $T_{7}, T_{1}$ and control. On the other hand, the lowest fruit length of tomato (L. esculentum) was obtained from the $T_{5}$ treatment. The average fruit diameter of tomato ranged from $3.18-3.75 \mathrm{~cm}$ with a mean value of $3.50 \mathrm{~cm}$ (Table 1). The highest fruit diameter of tomato was obtained from the treatment $\mathrm{T}_{2}$ (i.e. soil application of chitosan @ 120 ppm) followed by $T_{7}, T_{4}, T_{11}, T_{1}$ and control. On the other hand, the lowest fruit diameter of tomato (L. esculentum) was obtained from the $T_{10}$ treatment. So, it can be inferred from the present study results that fruit length and diameter of tomato (L. esculentum) are not affected by the different application method and concentration of chitosan. Similarly, number of fruits plant ${ }^{-1}$ of tomato (L. esculentum) also did not vary significantly by the effect of different application methods and concentration of chitosan (Table 1). The maximum number of fruits plant $^{-1}$ of tomato was obtained from the treatment $\mathrm{T}_{6}$ (i.e. combination of soil and foliar application of chitosan @ 80 ppm and 60 ppm, respectively) followed by $T_{7}, T_{9}, T_{10}$ and $T_{3}$. On the other hand, the minimum number of fruits plant ${ }^{-1}$ of tomato was rec- orded from the control plant followed by $T_{5}, T_{1}$ and $T_{2}$ treatments. Present study results revealed that number of fruits plant $^{-1}$ of tomato (L. esculentum) increased by the different application method and concentration of chitosan although the results were insignificant. On the contrary, several study reported that foliar spraying of chitosan has positive significant effect on number of fruits plant ${ }^{-1}$ of tomato (Mondal et al., 2016; Sultana et al., 2017).

Different application methods and levels of chitosan had insignificant effect on single fruit weight of tomato (Table 1). Single fruit weight of tomato (L. esculentum) varied from 33.35-40.90 g with an average value of $36.08 \mathrm{~g}$ among the treatments. The highest single fruit weight of tomato ( $L$. esculentum) was obtained from the treatment $\mathrm{T}_{6}$ (i.e. combination of soil and foliar application of chitosan @ 80 ppm and 60 ppm, respectively) followed by $T_{7}, T_{3}$ and $T_{1}$. On the other hand, the lowest single fruit weight of tomato (L.esculentum) was recorded from the $T_{11}$ followed by control and $T_{10}$ treatments. This result indicates that fruit size and weight was largely controlled by inherently. However, Sultana et al. (2017) reported that the average number of fruits plot $^{-1}$ at different days after sowing (45-90) gradually increased with increasing concentration of chitosan up to 100 ppm. But the effect of different application methods and concentration of chitosan on fruit yield was statistically significant at $5 \%$ level of probability. The average fruit yield plant $^{-1}$ of tomato (L. esculentum) ranged from 418.48-663.54 g with a mean value of $418.48 \mathrm{~g}$ (Table 1). The highest fruit yield of tomato ( $L$. esculentum) was obtained from the treatment $T_{6}$ (i.e. combination of soil and foliar application of chitosan @ 80 ppm and 60 ppm, respectively) followed by $T_{7}, T_{9}$ and $T_{3}$ treatments. On the other hand, the lowest fruit yield of tomato (L. esculentum) was obtained from the control treatment. This result is at par with the research works done by Sultana et al. (2017) and Mondal et al. (2016), they stated that foliar spraying of oligo-chitosan with different concentrations has positive effect on fruit yield of tomato (L. esculentum).

Effect of chitosan application on biochemical parameters of tomato (L. esculentum)

Different application methods and concentrations of chitosan showed highly significant difference on biochemical parameters (vitamin-C, titratable acidity and lycopene) of tomato (L. esculentum) fruits (Table 2). Tomato is a good source of vitamin-C and according to Erba et al. (2013), the ingestion of $200 \mathrm{~g}$ of fresh tomatoes provides about $30 \%$ and $36 \%$ of the recommended dietary allowances for vitamin- $\mathrm{C}$ for men and women, respectively. The average vitamin- $C$ content of tomato fruits ranged from 2.19-4.09 mg $100 \mathrm{~g}^{-1}$ sample with a mean value of $3.05 \mathrm{mg}$ $100 \mathrm{~g}^{-1}$ sample (Table 2). The highest vitamin-C content in tomato (L. esculentum) fruits was obtained from the treatment $T_{4}$ (i.e. foliar application of chitosan @ 80 ppm) followed by $T_{5}$ and $T_{8}$ treatments. On the other hand, the lowest amount of vitamin- $\mathrm{C}$ was recorded from the treatment $T_{1}$ followed by $T_{2}$ and control. Present study results revealed that foliar application of chitosan alone or in combination with soil application significantly 
Table 1. Effect of different application methods and doses of chitosan on yield attributes and yield of tomato (L. esculentum).

\begin{tabular}{|c|c|c|c|c|c|c|c|}
\hline Treatment & $\begin{array}{c}\text { Number of } \\
\text { flower } \\
\text { cluster }\end{array}$ & $\begin{array}{c}\text { Flowering } \\
\text { duration } \\
\text { (day) }\end{array}$ & $\begin{array}{l}\text { Fruit } \\
\text { length } \\
(\mathrm{cm})\end{array}$ & $\begin{array}{l}\text { Fruit diameter } \\
\qquad(\mathrm{cm})\end{array}$ & $\begin{array}{l}\text { Number } \\
\text { of fruits } \\
\text { plant }^{-1}\end{array}$ & $\begin{array}{l}\text { Single fruit } \\
\text { weight } \\
\text { (g) }\end{array}$ & $\begin{array}{l}\text { Yield } \\
\text { plant }^{-1} \\
\text { (g) }\end{array}$ \\
\hline TO & $9.75 c$ & $65.00 \mathrm{e}$ & $4.58 a$ & 3.55 & 12.00 & 34.53 & $418.48 b$ \\
\hline $\mathrm{T} 1$ & $13.50 \mathrm{a}$ & $67.25 d$ & $4.56 a$ & 3.54 & 12.50 & 36.71 & 459.83ab \\
\hline $\mathrm{T} 2$ & $10.00 \mathrm{c}$ & $66.25 \mathrm{de}$ & $4.65 a$ & 3.75 & 12.50 & 35.00 & $437.43 b$ \\
\hline T3 & 13.25ab & $81.25 a$ & 4.28ab & 3.50 & 14.50 & 37.25 & 548.13ab \\
\hline $\mathrm{T} 4$ & $12.75 a b c$ & $72.50 \mathrm{~b}$ & $4.57 a$ & 3.58 & 13.50 & 35.25 & 477.37ab \\
\hline T5 & $13.75 a$ & $71.00 b c$ & $4.05 b$ & 3.30 & 12.25 & 35.57 & 442.43ab \\
\hline T6 & 11.00abc & $81.50 a$ & 4.44ab & 3.54 & 16.25 & 40.90 & $663.54 a$ \\
\hline $\mathrm{T7}$ & $13.75 a$ & $70.50 b c$ & $4.58 a$ & 3.63 & 15.25 & 38.56 & 600.80ab \\
\hline T8 & $12.50 \mathrm{abc}$ & $71.00 b c$ & 4.46ab & 3.44 & 12.50 & 35.31 & 442.63ab \\
\hline T9 & $11.50 \mathrm{abc}$ & $80.25 a$ & 4.33ab & 3.35 & 15.25 & 35.90 & $549.42 \mathrm{ab}$ \\
\hline T10 & $10.25 b c$ & $69.75 c$ & 4.21ab & 3.28 & 15.25 & 34.64 & 527.24ab \\
\hline $\mathrm{T} 11$ & $12.25 a b c$ & $70.25 c$ & 4.17ab & 3.55 & 13.00 & 33.35 & $421.39 b$ \\
\hline CV (\%) & 2.36 & 1.01 & 0.94 & 1.09 & 2.71 & 1.69 & 3.62 \\
\hline LSD & 1.82 & 1.27 & 0.28 & 0.29 & 2.74 & 4.70 & 128.52 \\
\hline Level of Significance & $*$ & $* *$ & $*$ & NS & NS & NS & $*$ \\
\hline
\end{tabular}

${ }^{*} \&^{* *}=$ Significant at 5 and $1 \%$ level of probability, respectively; NS= Not significant.

Table 2. Effect of different application methods and doses of chitosan on major biochemical and mineral constituents of tomato (L. esculentum).

\begin{tabular}{|c|c|c|c|c|c|c|c|c|c|}
\hline \multirow[b]{2}{*}{ Treatment } & \multirow{2}{*}{$\begin{array}{c}\text { Vitamin-C } \\
{\text { (mg } 100 \mathrm{~g}^{-1}}^{\text {sample) }}\end{array}$} & \multirow{2}{*}{$\begin{array}{c}\text { Total } \\
\text { acidity } \\
(\%)\end{array}$} & \multirow{2}{*}{$\begin{array}{l}\text { Lycopene } \\
\text { (mg } 100 \mathrm{~g}^{-1} \\
\text { sample) }\end{array}$} & \multicolumn{6}{|c|}{ Major mineral constituents in $\%$} \\
\hline & & & & $\mathrm{Ca}$ & $\mathrm{Mg}$ & $\mathrm{Na}$ & $\mathbf{K}$ & $S$ & $\mathbf{P}$ \\
\hline T0 & $2.63 \mathrm{~g}$ & 0.27 ef & $3.44 b$ & $0.64 b$ & $0.29 d$ & $0.34 b c$ & $0.535 f$ & $0.128 \mathrm{j}$ & 0.18de \\
\hline T1 & $2.19 \mathrm{~h}$ & $0.34 \mathrm{de}$ & $3.41 b$ & $0.58 c$ & $0.49 b$ & $0.36 a b$ & $0.623 a$ & $0.142 b$ & $0.15 \mathrm{ef}$ \\
\hline $\mathrm{T} 2$ & $2.63 g$ & $0.25 f$ & $2.54 \mathrm{e}$ & $0.48 d$ & $0.49 b$ & $0.36 \mathrm{ab}$ & $0.574 c$ & $0.132 \mathrm{~g}$ & 0.18de \\
\hline T3 & $2.92 f$ & $0.34 \mathrm{de}$ & $3.21 c$ & $0.32 \mathrm{e}$ & $0.58 a$ & $0.36 a b$ & $0.533 f$ & $0.132 f$ & $0.17 \mathrm{de}$ \\
\hline T4 & $4.09 a$ & $0.41 b c$ & $3.17 c$ & $0.64 b$ & $0.39 c$ & $0.36 a b$ & $0.568 d$ & $0.151 a$ & $0.13 f$ \\
\hline T5 & $3.65 b$ & $0.36 d$ & $2.38 f$ & $0.48 d$ & $0.29 d$ & $0.26 \mathrm{e}$ & $0.364 k$ & $0.139 d$ & $0.15 \mathrm{ef}$ \\
\hline T6 & $2.90 f$ & $0.35 \mathrm{de}$ & $3.55 a$ & $0.64 b$ & $0.39 c$ & $0.33 \mathrm{bcd}$ & $0.520 \mathrm{~g}$ & $0.135 \mathrm{e}$ & $0.33 a$ \\
\hline T7 & $3.40 c$ & $0.39 b c$ & $3.17 c$ & $0.69 a$ & $0.39 c$ & $0.33 \mathrm{bcd}$ & $0.589 b$ & $0.131 \mathrm{~h}$ & $0.26 b$ \\
\hline T8 & $3.60 c$ & $0.62 a$ & $2.24 \mathrm{~g}$ & $0.48 d$ & $0.29 d$ & $0.38 a$ & $0.553 e$ & $0.135 \mathrm{e}$ & $0.19 \mathrm{~cd}$ \\
\hline T9 & $3.36 c$ & $0.46 b$ & $3.23 c$ & $0.48 d$ & $0.29 d$ & $0.30 \mathrm{~d}$ & $0.456 i$ & $0.129 i$ & $0.19 \mathrm{~cd}$ \\
\hline T10 & $3.04 \mathrm{e}$ & $0.41 b c$ & $3.58 a$ & $0.48 d$ & $0.49 b$ & $0.32 \mathrm{~cd}$ & $0.507 \mathrm{~h}$ & $0.140 c$ & $0.16 \mathrm{def}$ \\
\hline T11 & $3.21 \mathrm{~d}$ & $0.37 c$ & $2.95 d$ & $0.64 b$ & $0.29 d$ & $0.31 \mathrm{~cd}$ & $0.434 j$ & $0.122 k$ & $0.22 c$ \\
\hline CV (\%) & 2.72 & 4.37 & 2.41 & 3.26 & 4.33 & 1.82 & 2.26 & 0.93 & 4.86 \\
\hline LSD & 0.044 & 0.044 & 0.062 & 0.014 & 0.010 & 0.014 & 0.010 & 0.017 & 0.010 \\
\hline Level of Significance & $* *$ & $* *$ & $* *$ & $* *$ & $* *$ & $* *$ & $* *$ & $* *$ & $* *$ \\
\hline
\end{tabular}

** $=$ Significant at $1 \%$ level of probability.

increase vitamin- $\mathrm{C}$ content in tomatoes, but there were some inconsistencies which might be due to stage of maturity of fruits, size as well as environmental factors. This result is similar to the reports published by Abd El-Gawad and Bondok (2015) and Sultana et al. (2017). According to Khan et al. (2002), the pronounced promotional effect of chitosan on vitamin-C content compared with control could be due to the enhanceable nature of chitosan on photosynthesis process that strongly correlated with the synthesis of sugars, polysaccharides and vitamins. Chitosan served as a plant growth promoters may be due to an increase in the availability and uptake of water and essential nutrients through adjusting cell osmotic pressure and reducing the accumulation of harmful free radicals by increasing antioxidants and enzyme activities (Guan et al., 2009).

The highest amount of total acidity was found at $\mathrm{T}_{8}$ treatment $(0.62 \%)$ followed by $T_{9}, T_{10}$ and $T_{4}$ treatments. On the other hand, the lowest amount of total acidity was obtained from the control treatment which was statistically at par with $T_{1}, T_{2}$ and $\mathrm{T}_{3}$ treatments (Table 2). So, it can be inferred from this study results that combined application of chitosan increased total acidity compared to control and foliar treatments. But Ghoname et al. (2010) reported that spraying with chitosan showed positive responses on total acidity content of sweet pepper. On the contrary, Sultana et al. (2017) reported that foliar application of chitosan showed reduction in acidity compared to control samples in tomato (L. esculentum). Similarly, Meng et al. (2008), stated that total acidity of the grape fruit decreased with increase in maturity and was not significantly affected by preharvest chitosan spraying treatment. However, there were some variations in results that might be due to maturity status of fruits, size as well as environmental factors.

Lycopene is one kind of carotenoids responsible for the red colour of tomato (L. esculentum). Epidemiological, as well as cell culture and animal studies suggest that lycopene and the consumption of lycopene containing foods may reduce cancer or cardiovascular disease risk (Story et al., 2010). The amount of lycopene obtained from different treatments of tomato fruits are presented in Table 2. The average lycopene content of tomato 


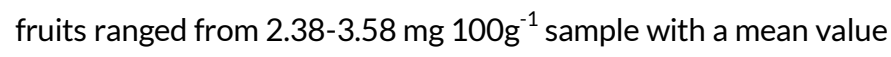
of $3.07 \mathrm{mg} 100 \mathrm{~g}^{-1}$ sample (Table 2). The highest amount of lycopene in tomato fruits was obtained from the treatment $T_{10}$ (i.e. soil application of chitosan @ 120 ppm + foliar application of chitosan @ 80 ppm), which was statistically at par with $\mathrm{T}_{6}$ treatment (i.e. soil application of chitosan @ 80 ppm + foliar application of chitosan @ 60 ppm). On the other hand, the lowest amount of lycopene was recorded from the treatment $T_{5}$ followed by $T_{2}$. Present study results revealed that foliar application of chitosan alone or in combination with soil application significantly increased lycopene content in tomatoes, but there were some inconsistencies in obtained result which might be due to stage of maturity of fruits, size as well as environmental factors. According to Meng et al. (2008), the activities of superoxide dismutase decreased by the application of chitosan treatments and postharvest chitosan spraying/coating treatments also changed the activities of polyphenol oxidase, peroxidase and phenylalanine ammonia-lyase. They also stated that total phenolic compounds content in preharvest chitosan spraying treated fruit decreased but then increased at the end of the storage period.

Effect of chitosan application on mineral contents of tomato fruits

The highest amount of $\mathrm{Ca}$ was found at $\mathrm{T}_{7}$ treatment $(0.69 \%)$ followed by $T_{4}, T_{6}, T_{11}$ and control treatments. On the other hand, the lowest amount of $C a$ was obtained from the $T_{3}$ treatment (Table 2). So, it can be inferred from this study results that application of chitosan had positive effect on total $\mathrm{Ca}$ content of tomato (L. esculentum) fruits. Paul and Shaha (2004) stated that citrus fruits are not considerable to be the good sources of $\mathrm{Ca}$, but some fruits may contain appreciable amount of $\mathrm{Ca}$. However, they obtained $27.0 \pm 1.2 \mathrm{mg} \% \mathrm{Ca}$ in tomato fruits collected from the northern region of Bangladesh. According to Olaniyi et al. (2010), the tomato variety Roma VF contained $0.376 \% \mathrm{Ca}$, which was a bit lower compared to the present study.

The Mg content in tomato (L. esculentum) fruits ranged from 0.29 $-0.58 \%$ with a mean value of $0.39 \%$ (Table 2). The highest amount of $\mathrm{Mg}$ was obtained from the treatment $\mathrm{T}_{3}$ (foliar application of chitosan @ 60 ppm), while the lowest amount of $\mathrm{Mg}$ was found in control treatment which was statistically similar to $\mathrm{T}_{5}, \mathrm{~T}_{8}, \mathrm{~T}_{9}$, and $\mathrm{T}_{11}$ treatments. Present study results revealed that foliar application of chitosan had positive effect on total $\mathrm{Mg}$ content of tomato fruits. Paul and Shaha (2004) reported $17.0 \pm 1.8 \mathrm{mg} \% \mathrm{Mg}$ in tomato fruits collected from the northern region of Bangladesh. According to Olaniyi et al. (2010), the tomato variety Roma VF contained $0.222 \% \mathrm{Mg}$, which was almost similar to the present study.

Different application methods and level of chitosan showed highly significant effect on $\mathrm{Na}$ and $\mathrm{K}$ contents of tomato (L. esculentum) fruits (Table 2). The highest amount of $\mathrm{Na}$ was found at $T_{8}$ treatment (0.38\%), which was statistically similar to $\mathrm{T}_{1}, \mathrm{~T}_{2}, \mathrm{~T}_{3}$ and $\mathrm{T}_{4}$ treatments. In case of $\mathrm{K}$, the maximum amount was obtained from the treatment $T_{1}$ followed by the $T_{7}, T_{2}$ and $T_{4}$ treatments. On the other hand, the lowest amount of $\mathrm{Na}$ and $\mathrm{K}$ was obtained from the $T_{5}$ treatment. So, it can be inferred from this study results that both soil and foliar application of chitosan had positive effect on total $\mathrm{Na}$ and $\mathrm{K}$ content of tomato (L. esculentum) fruits. Paul and Shaha (2004) reported $5.5 \pm 0.9 \mathrm{mg} \% \mathrm{Na}$ and $275 \pm 2.8 \mathrm{mg} \% \mathrm{~K}$ in tomato fruits collected from the northern region of Bangladesh. According to Olaniyi et al. (2010), the tomato variety Roma VF contained $0.148 \% \mathrm{~K}$. But Mukta et al. (2015) stated that the $K$ content in tomato fruits varied from 0.76 to $0.90 \%$.

Similar to other mineral nutrients, different application methods and level of chitosan also showed highly significant effect on $\mathrm{S}$ and $\mathrm{P}$ contents of tomato (L. esculentum) fruits (Table 2). The highest amount of $S$ was found at $T_{4}$ treatment $(0.151 \%)$, followed by the treatments $T_{1}(0.142 \%), T_{10}(0.140 \%)$ and $T_{5}$ $(0.139 \%)$. On the other hand, the lowest amount of $S$ was obtained from the $\mathrm{T}_{11}$ treatment followed by control. According to Mukta et al. (2015), the content of $S$ in tomato fruits varied from 0.05 to $0.39 \%$, and present study results were within this range. The $P$ content in tomato ( $L$. esculentum) fruits ranged from $0.13-0.33 \%$ with a mean value of $0.19 \%$. The highest amount of $P$ was obtained from the treatment $T_{6}$ followed by the $T_{7}$ and $T_{11}$ treatments. On the other hand, the lowest amount of $P$ was found in $T_{4}$ treatment. Paul and Shaha (2004) stated that citrus fruits are not good source of $P$ although they reported 28.0 \pm 1.8 $\mathrm{mg} \% \mathrm{P}$ in tomato fruits collected from the northern region of Bangladesh. According to Olaniyi et al. (2010), the tomato variety Roma VF contained $0.445 \% \mathrm{P}$, which was comparatively higher than this study. But Kadiri et al. (2015) reported $1.02 \pm 0.01 \mathrm{mg} \mathrm{kg}^{-1} \mathrm{P}$ in tomato fruits, which was very much smaller than the present study. However, there were some inconsistencies in major nutrients content which might be due to stage of maturity of fruits, size as well as environmental factors.

\section{Conclusion}

Different application methods and levels of chitosan had significant effect on number of leaves, number of flower clusters, flowering duration, fruit length, yield, major biochemical and mineral nutrients of tomato (L. esculentum). The highest fruit yield and lycopene content of tomato were obtained from the treatments $\mathrm{T}_{6}$ (i.e. soil application of chitosan @80 ppm + foliar application of chitosan @60 ppm) and $\mathrm{T}_{10}$ (i.e. soil application of chitosan @120 ppm + foliar application of chitosan @80 ppm), respectively. On the other hand, treatment $\mathrm{T}_{4}$ (i.e. foliar application of chitosan @ 80 ppm) was more effective concerning most of the growth and biochemical parameters of tomato (L. esculentum). Thus, it can be summarized from the present study results that foliar application of chitosan alone or in combination with soil application has significant effect on growth, yield and biochemical characters of tomato (L. esculentum) fruits, but there were some inconsistencies which might be due to stage of maturity of fruits, size as well as environmental factors. So, before final recommendation of application dose and method of chitosan, further study is needed in different years and agroecological zones of Bangladesh. 
Open Access: This is an open access article published under the terms and conditions of Creative Commons AttributionNonCommercial 4.0 International License which permits noncommercial use, distribution, and reproduction in any medium, provided the original author(s) if the sources are credited.

\section{REFERENCES}

Abd El-Gawad, H.G. and Bondok, A.M. (2015). Response of tomato plants to salicylic acid and chitosan under infection with tomato mosaic virus. AmericanEurasian Journal of Agricultural and Environmental Sciences, 15: 1520-1529, https://dx.doi.org/10.5829/idosi.aejaes.2015.15.8.12735

BBS (Bangladesh Bureau of Statistics). (2019). Statistical Pocket Book Bangladesh 2018. Ministry of Planning, Government of the People's Republic of Bangladesh. Dhaka, Bangladesh. pp. 148, Retrieved from http://www.bbs.gov.bd/

Bittelli, M.M., Flury, G., Campbell, S. and Nichols, E.J. (2001). Reduction of transpiration through foliar application of chitosan. Agricultural and Forest Meteorology, 107: 167-175, https://dx.doi.org/10.1016/S0168-1923(00)00242-2

Bolto, B., Dixon, D. and Eldridge, R. (2004). Ion exchange for the removal of natural organic matter. Reactive and Functional Polymers, 60: 171-182, https://dx.doi.org/10.1016/j.reactfunctpolym.2004.02.021

Boonlertnirun, S., Boonraung, C. and Suvanasara, R. (2008). Application of chitosan in rice production. Journal of Metals, Materials and Minerals, 18(2): 47-52.

Doares, S.H., Syrovets, T., Weiler, E.W. and Ryan, C.A. (1995). Oligogalacturonides and chitosan activate plant defensive gene through the octadecanoid pathway. Proceedings of the National Academy of Sciences, 92: 4095-4098.

Dutta, P.K., Tripathi, S., Mehrotra, G.K. and Dutta, J. (2009). Perspectives for chitosan based antimicrobial films in food applications. Food Chemistry, 114 (4): 1173-1182, https://dx.doi.org/10.1016/j.foodchem.2008.11.047

El-Tantawy, E.M. (2009). Behavior of tomato plants as affected by spraying with chitosan and aminofort as natural stimulator substances under application of soil organic amendments. Pakistan Journal of Biological Sciences, 12: 1164-1173, https://dx.doi.org/10.3923/pjbs.2009.1164.1173

Erba, D., Casiraghi, M.C., Ribas, A., Cáceres, R., Marfà, O. and Castellari, M. (2013). Nutritional value of tomatoes (Solanum lycopersicum L.) grown in greenhouse by different agronomic techniques. Journal of Food Composition and Analysis, 31(2): 245-251, https://dx.doi.org/10.1016/j.jfca.2013.05.014

FRG (Fertilizer Recommendation Guide). (2012). Bangladesh Agricultural Research Council (BARC), Farmgate, Dhaka-1215, Retrieved from www.barc.gov.bd

Gabriela, M.S., Nicolás E.F., Leticia A.P., Sam C. and Carlos R.F. (2016). Effects of preharvest applications of methyl jasmonate and chitosan on postharvest decay, quality and chemical attributes of Fragaria chiloensis fruit. Food Chemistry, 190: 448-453, https://dx.doi.org/10.1016/j.foodchem.2015.05.107

Geisberger, G., Gyenge, E.B., Hinger, D., Kach, A., Maake, C. and Patzke, G.R. (2013). Chitosan-thioglycolic acid as a versatile antimicrobial agent. Biomacromolecules, 14(4): 1010-1017, https://dx.doi.org/10.1021/bm3018593

Ghoname, A.A., El-Nemr, M.A., Abdel-Mawgoud, A.M.R. and El-Tohamy, W.A. (2010). Enhancement of sweet pepper crop growth and production by application of biological, organic and nutritional solutions. Research Journal of Agriculture and Biological Sciences, 6: 349-355.

Gol, N.B., Patel, P.R. and Rao, T.V. (2013). Improvement of quality and shelf-life of strawberries with edible coatings enriched with chitosan. Postharvest Biology and Technology, 85: 185-195, https://dx.doi.org/10.1016/j.postharvbio.2013.06.008

Gornik, K., Grzesik, M. and Romanowska-Duda, B. (2008). The effect of chitosan on rooting of grapevine cuttings and on subsequent plant growth under drought and temperature stress. Journal of Fruit and Ornamental Plant Research, 16: 333-343.

Guan, Y.J., Hu, J., Wang, X.J. and Shao, C.X. (2009). Seed priming with chitosan improves maize germination and seedling growth in relation to physiological changes under low temperature stress. Journal of Zhejiang University of Science B, 10: 427-433, https://dx.doi.org/10.1631/jzus.B0820373

Hadwiger, L.A. (2013). Plant science review: Multiple effects of chitosan on plant systems: Solid science or hype. Plant Science, 208: 42-49, https://dx.doi.org/10.1016/j.plantsci.2013.03.007

Huang, J.Y., Chen, Q.C., Qiu, M. and Li, S.Q. (2012). Chitosan-based edible coatings for quality preservation of postharvest white leg shrimp (Litopenaeus vannamei). Journal of Food Science, 77(4): C491-C496, https://dx.doi.org/10.1111/j.1750-3841

Jabeen, N. and Ahmad, R. (2013). The activity of antioxidant enzymes in response to salt stress in safflower (Carthamus tinctorius L.) and sunflower (Helianthus annuus L.) seedlings raised from seed treated with chitosan. Journal of the Science of Food and Agriculture, 93(7): 1699-1705 https://dx.doi.org/10.1002/jsfa.5953

Kadiri, M., Ojewumi, A.W. and Olawale, S.O. (2015). Minerals, vitamins and chlorophyll contents of fruits, stems and leaves of tomato and garden egg. Pakistan Journal of Food Science, 25(3): 150-154.

Khan, W.M., Prithiviraj, B. and Smith, D.L. (2002). Effect of foliar application of chitin and chitosan oligosaccharides on photosynthesis of maize and soybean. Photosynthetica, 40: 621-624, https://dx.doi.org/10.1023/A:1024320606812

Lizarraga-Pauli, E.G., Torres-Pacheco, I., Moreno Martinez, E. and Miranda-Castro, S.P. (2011). Chitosan application in maize (Zea mays) to counteract the effects of abiotic stress at seedling level. African Journal of Biotechnology, 10 (34): 6439-6446, https://dx.doi.org/10.5897/ajb10.1448

Meng, X., Li, B., Liu, J. and Tian, S. (2008). Physiological responses and quality attributes of table grape fruit to chitosan preharvest spray and postharvest coating during storage. Food Chemistry, 106: 501-508, https://dx.doi.org/10.1016/j.foodchem.2007.06.012

Miao, Q., Chu, W., Gerui, R., Xinle, L., Xiangyang, W. and Jianying, H. (2014). Effect of chitosan and its derivatives as antifungal and preservative agents on postharvest green asparagus. Food Chemistry, 155: 105-111, https://dx.doi.org/10.1016/j.foodchem.2014.01.026

Mondal, M.M.A., Puteh, A.B. and Dafader, N.C. (2016). Pakistan Journal of Agricultural Sciences, 53: 339-344, https://dx.doi.org/10.21162/pakjas/16.2011

Mukta, S., Rahman, M.M. and Mortuza, M.G. (2015). Yield and nutrient content of tomato as influenced by the application of vermicompost and chemical fertilizers. Journal of Environmental Science and Natural Resources, 8(2): 115122, https://dx.doi.org/10.3329/jesnr.v8i2.26877

Nguyen Van, S., Dinh Minh, H. and Nguyen Anh, D. (2013). Study on chitosan nanoparticles on biophysical characteristics and growth of Robusta coffee in green house. Biocatalysis and Agricultural Biotechnology, 2(4): 289-294, https://dx.doi.org/10.1016/j.bcab.2013.06.001

No, H.K., Park, N.Y., Lee, S.H. and Meyers, S.P. (2002). Antibacterial activity of chitosans and chitosan oligomers with different molecular weights. International Journal Food Microbiology, 74: 65-72, https://dx.doi.org/10.1016/S0168-1605(01)00717-6

Olaniyi, J.O., Akanbi, W.B., Adejumo, T.A. and Akande, O.G. (2010). Growth, fruit yield and nutritional quality of tomato varieties. African Journal of Food Science, 4(6): 398-402, Retrieved from http://www.academicjournals.org/ajfs

Paul, D.K. and Shaha, R.K. (2004). Nutrients, vitamins and minerals content in common citrus fruits in the northern region of Bangladesh. Pakistan Journal of Biological $\quad$ Sciences, $23(2)$ : https://dx.doi.org/10.3923/pjbs.2004.238.242

Pongprayoon, W., Roytrakul, S., Pichayangkura, R. and Chadchawan, S. (2013). The role of hydrogen peroxide in chitosan-induced resistance to osmotic stress in rice (Oryza sativa L.). Plant Growth Regulation, 70(2): 159-173, https://dx.doi.org/10.1007/s10725-013-9789-4

Sadasivam, S. and Manickam, A. (1996). Biochemical Methods. $2^{\text {nd }}$ Edition, New Age International (P) Limited, New Delhi-110 002, India.

Singh, D., Chhonkar, P.K. and Pandey, R.N. (1999). Soil, Plant and Water Analysis: A Method Manual. IARI, New Delhi. India.

Story, E.N., Kopec, R.E., Schwartz, S.J. and Harris, G.K. (2010). An update on the health effects of tomato lycopene. Annual review of food science and technology, 1: 189-210, https://dx.doi.org/10.1146/annurev.food.102308.124120

Sultana, N., Zakir, H.M., Parvin, M.A., Sharmin, S. and Seal, H.P. (2019). Physiological responses and nutritional qualities of tomato fruits to chitosan coating during postharvest storage. Asian Journal of Advances in Agricultural Research, 10(2): 1-11, https://dx.doi.org/10.9734/AJAAR/2019/v10i230027

Sultana, S., Islam, M., Khatun, M.A., Hassain, M.A. and Huque, R. (2017). Effect of foliar application of oligo-chitosan on growth, yield and quality of tomato and eggplant. Asian Journal of Agricultural Research, 11: 36-42, https://dx.doi.org/10.3923/ajar.2017.36.42

Zhang, X., Geng, X.D., Jiang, H.J., Li, J.R. and Huang, J.Y. (2012). Synthesis and characteristics of chitin and chitosan with the [(2-Hydroxy-3trimethylammonium) propyl] functionality, and evaluation of their antioxidant activity in vitro. Carbohydrate Polymers, 89(2): 486-491, https://dx.doi.org/10.1016/j.carbpol.2012.03.032 